\title{
Legislation on meliponiculture in Brazil: a social and environmental demand
}

\author{
Legislação sobre meliponicultura no Brasil: demanda \\ social e ambiental
}

\author{
Jaqueline Reginato Koser ${ }^{\mathrm{a}}$ \\ Celso Barbiérib \\ Tiago Maurício Francoy ${ }^{\mathrm{c}}$
}

${ }^{a}$ Faculdade de Medicina de Ribeirão, Universidade de São Paulo, Preto Ribeirão Preto, SP, Brasil End. Eletrônico: jaquelinekoser@gmail.com

${ }^{b}$ Programa de Pós graduação em Sustentabilidade, Escola de Artes Ciências e Humanidades, Universidade de São Paulo, São Paulo, SP, Brasil End. Eletrônico: celso.barbieri@gmail.com

'Escola de Artes Ciências e Humanidades, Universidade de São Paulo, São Paulo, SP, Brasil. End. Eletrônico: tfrancoy@usp.br.

doi:10.18472/SustDeb.v11n1.2020.30319

Received: 27/03/2020

Accepted: 09/04/2020

ARTICLE- VARIA

\begin{abstract}
American stingless bee species have been kept and managed by local civilizations since the pre-Columbian era, with many species currently managed in commercial meliponaries. However, divergences exist among authors about the ecological utility of these practices. Some argue that meliponaries could serve to maintain local biodiversity, while others argue that they have the opposite effect. Due to pressure from beekeepers and environmentalists, there are efforts to draft specific rules that legislate production and market, focusing on conserving native bees. In recent years, these legislation have become more specific due to the use of empirical data from the scientific community and demands from social groups and producers. This paper presents a revision on Brazilian legislation as well its applicabilities and proposes alterations in the Environmental Crimes Law.
\end{abstract}

Keywords: Stingless bees. Environmental laws. Meliponiculture. Bee products.

\section{RESUMO}

As espécies de abelhas produtoras de mel e própolis nativas do continente americano têm sido usadas em práticas de manejo e reprodução por civilizações locais desde tempos pré-colombianos. Atualmente, muitas dessas espécies são manejadas comercialmente e mantidas em meliponários. No entanto, existem, na literatura, divergências sobre a utilidade ecológica dessas práticas. Alguns autores argumentam que os meliponários são fontes de manutenção da biodiversidade local, enquanto outros argumentam que eles têm o efeito oposto. Devido à pressão dos meliponicultores e ambientalistas, 
há esforços para elaborar regras específicas que legislem a produção e o mercado, focando na conservação das abelhas nativas. Nos últimos anos, essas normas tornaram-se mais específicas devido ao uso de dados empíricos da comunidade científica, e buscam atender a demanda dos grupos sociais e produtores. Este artigo propõe uma revisão da legislação brasileira, bem como sua aplicabilidade, $e$ propõem alterações na Lei de Crimes Ambientais.

Palavras-Chave: Abelhas sem ferrão. Legislação ambiental. Meliponicultura. Produtos apícolas.

\section{INTRODUCTION}

Native species of social bees are kept and managed in the Americas since the pre-European colonization era. This relationship is so intimate that the stingless bees of the Meliponini tribe are commonly called indigenous bees (BALLIVIÁN, 2008; NEGRÍN MUÑOZ, 2016). This tribe has around 400 cataloged species in the Neotropical region (CAMARGO; PEDRO, 2013) and corresponds to about half of the animals that pollinate tropical plants. In Brazil, depending on the biome, they are responsible for up to $90 \%$ of native flora pollination (BARBOSA et al., 2017; KERR; CARVALHO-ZILSE; NASCIMENTO, 1996).

Their honey has a market value of about eight times more expensive than hone from Apis species (GEHRK, 2010). Another important market is related to colonies and larvae disks (GEHRK, 2010; VELTHUIS; KOEDAM; IMPERATRIZ-FONSECA, 2005). Although sometimes illegally, in some regions, colony sales represent a more substantial share in the earnings of beekeepers than the sale of honey, given the popularization of the activity (KOSER; FRANCOY, 2019).

Stingless bees have a high potential for the pollination of several economically important crops (CHAM et al., 2019), such as strawberries (ALVES, 2019) and tomatoes (VINíCIUS-SILVA et al., 2017). The maintenance of these bees in meliponaries makes the colonies transportable to agricultural systems, such as greenhouses, ensuring the presence of pollinators at the necessary time for each crop (BAPTISTA et al., 2018; JAFFÉ et al., 2015). Unlike species of the genus Apis (BUCHMANN, 1983), some Meliponini bees can vibrate the abdomen without damaging the flower (BUCHMANN, 1974; NUNES-SILVA; HRNCIR; IMPERATRIZ-FONSECA, 2010; VINÍCIUS-SILVA et al., 2017), avoiding floral fall and producing heavier and better quality fruits. At the same time, as they are native to the Americas, they are well adapted to the climate and offer no danger during the handling of the colonies, as they have a stunted stinger (MCGREGOR, 1976). Therefore, they are an excellent alternative for pollination in greenhouses and open environments, a market practically untapped by Brazilian beekeepers (DOS SANTOS; OTESBELGUE; BLOCHTEIN, 2018; JAFFÉ et al., 2015).

As most beekeepers do not have records and do not issue purchase and sale receipts, there are no real estimates of the economic movement of meliponiculture in Brazil. The municipality of Santa Rosa de Lima, in the Brazilian state of Santa Catarina state, is collecting this data. The city, with just over 2 thousand inhabitants, is considered a meliponiculture pole: about 70 families maintain more than 10,000 colonies, which can be multiplied and sold between 150 to 400 reais (personal communication ${ }^{1}$ ).

Meliponary is the name given to environments where colonies of stingless bees are kept. Traditionally, the formation of a meliponary involves the relocation of natural nests to a specific location. These nests may be transported with or without the trunk portion where the nest was found initially. However, in the last decades, these practices were abandoned, and the so-called rational beekeeping has developed. Nowadays, during copulation and dispersal periods, the newly fertilized queen and some workers are attracted to a trap nest. Trap nests are made with wooden boxes, PET bottles, or other artificial cavities that offer an attractive nesting site and allow free foraging for workers. Subsequently, these nests are transferred to rational hives that allow the honey collection and artificial multiplication, thus preventing the predatory removal of new colonies from nature (VELTHUIS; KOEDAM; IMPERATRIZ-FONSECA, 2005). 
The cheapest and quickest way to increase the number of colonies is to multiply the nests by dividing the emerging brood combs. For this technique, only a new wooden hive and a colony large enough to divide are needed. Increasing the number of colonies is essential for obtaining bee products or even for the trade of these new colonies.

The meliponiculture, both as a subsistence practice and as a hobby, has become increasingly popular in recent years, making commercial and hobbyist beekeepers great maintainers of stingless bee colonies (BARBIÉRI, 2018; GEHRK, 2010; JAFFÉ et al., 2015; VELTHUIS; KOEDAM; IMPERATRIZ-FONSECA, 2005). The interest in the practice, and its potential for expansion, can be observed by comparing the number of members in associations and on social media pages dedicated to the subject. For example, Jaffé et al. (2015) estimated about 5,000 meliponists legally registered in Brazil, while the page Meliponicultura - Abelhas Brasileiras sem Ferrão, has around 14,000 members.

On a local scale, an example is the Associação de Meliponicultores de Blumenau (AME Blumenau), which has more than 180 members, while the web page Meliponicultores do Vale de Santa Catarina, where this municipality is located, has more than 1,200 members. However, the census of the singles beekeepers has some obstacles. Barbiéri (2018) made an online questionnaire and voluntarily obtained data from 280 meliponists in the Brazilian State of São Paulo. However, these numbers are underreported. Both the lack of access to technological tools and the fear of exposure that many beekeepers declare are some possible reasons.

Unlike traditional agricultural activities, beekeepers have the potential to help reduce the need for deforestation and the exploration of new habitats and natural resources. Also, they can promote interaction experiences between man and the environment, stimulating conservation attitudes, emotional ties with natural elements and environmental reflection, in addition to increasing popular participation in environmental policies (ATHAYDE; STEPP; BALLESTER, 2016; CARVALHO et al., 2018; CHANTHAYOD; ZHANG; CHEN, 2017; JAFFÉ et al., 2015; MADERSON; WYNNE-JONES, 2016).

However, the conservation of the diversity and genetic identity of economically exploited species is often contrary to the commercial interests of the beekeepers. In this case, definitions of management practices and standards can unite conservation and production interests, as in the case of fish, such as salmon (SCHENEKAR; LERCETEAU-KHLER; WEISS, 2014), palm trees like the butiá (NAZARENO; DOS REIS, 2014) and insects, especially bees (BONATTI et al., 2014; MUÑOZ et al., 2014; SANTIAGO et al., 2016).

The knowledge of the diversity maintained by producers can contribute to the adequacy and regulation of this activity as a recognized bank of native genetic diversity and as a source of colonies for reintroduction and conservation. Given the above, there must be a more significant commitment from conservation programs and more incentive to adopt sustainable improvement programs. It should include small farmers within this developmental scenario to expand the internal market, generating higher economic expectations and, consequently, preserving biodiversity and natural resources needed for development (SILVA et al., 2014).

There are initiatives in this regard, such as the Manduri Project, the first financed by the Brazilian Federal Government that aims the reintroduction of native bees and training of bee breeders for socioeconomic and conservationist purposes in the Rio Grande do Sul State (ASSOCIAÇÃO PAPA-MEL DE APICULTORES DE ROLANTE, 2006). Another example is the Strengthen Plan for the Apiculture and Meliponiculture Production Chain of São Paulo State (SÃO PAULO, 2018), which delimits planning units into small socio-political divisions.

However, the ecological role of meliponaries is controversial. Studies on Apis mellifera indicate strong disagreement on the role of artificial bee maintenance, with contradictory results indicating deterioration (DE LA RÚA et al., 2013), or the support or even the increase of local genetic diversity (HARPUR et al., 2012 , 2013). The consensus is that the diversity in meliponaries reflects the handling and transportation practices that producers carry out in maintaining production (SANTIAGO et al., 2016). 
Therefore, breeding and management can reflect or alter the local genetic stock. Thus, there are several factors, unfavorable and favorable, to be analyzed regarding the bee colonies' management. Additionally, it is worth to mention that essential conclusions from decades of research in conservation genetics remain within the scientific community and are often not translated into concrete actions in the development of international conservation policies (LAIKRE, 2010).

\section{MELIPONICULTURE LEGISLATION DEVELOPMENT}

Due to the limited knowledge about genetic diversity and the management consequences, several specific laws regulate the ASF creation seeking their natural state of conservation. The rearing of native bees colonies and its commercialization are subject to federal and state normative instruments, and, until recently, there was no specific legislation for the maintenance of social insects.

Therefore, legislation was based on the precautionary principle, mentioned in the Declaration of the United Nations Conference on Sustainable Development - Rio/92. The definition of the precautionary principle is "the guarantee against potential risks that, according to the current state of knowledge, cannot yet be identified" (MINISTÉRIO DO MEIO AMBIENTE). Thus,

For the environment to be protected, preventive measures should be applied by States, according to their capabilities. Where there are threats of serious or irreversible risks, the lack of total scientific certainty can not be used as a reason for the postponement of cost-effective measures to prevent environmental degradation (MINISTÉRIO DO MEIO AMBIENTE).

Due to restrictive and no specific laws, the meliponiculture activity occurred, most of the times, irregularly under the legislation (CORTOPASSI-LAURINO et al., 2006; GEHRK, 2010), and until 2015, more than half of the great Brazilian commercial beekeepers pointed to the current legislation as the biggest obstacle of the activity (JAFFÉ et al., 2015). Public demonstrations in tribunes and meetings promoted by associations of municipalities with political entities demonstrated the sector difficulties and exerted considerable pressure, resulting in the evolution of legislation in recent years (DALMAGRO, 2015; G1 BA, 2017; NSC TV, 2019).

The legal framework that regulates Brazilian meliponiculture has a series of peculiarities and contradictions that can be detrimental to the development of the activity and the conservation of managed bee species. For meliponiculture, there are two types of relevant standards, those related to beekeeping and those related to the stingless bee product chains, such as honey, pollen, propolis, and others.

In the case of the rules for the keeping of stingless bees, the Portaria IBAMA (Brazilian Institute of Environment and Renewable Natural Resources) $n^{\circ} 117$ (BRASIL, 1997a) which regulates the trade of native wild animals (art. $10^{\circ}$ ) was one of the first, followed by the Portaria IBAMA N ${ }^{\circ}$ 118-N (BRASIL, 1997b), which regulates the keeping of wild animals for commercial purposes. Both require individual marking (art. $7^{\circ}$ ), containing age and sex information.

The marking and individualization of each bee indicate that the elaboration of these ordinances does not consider the biology of social insects. Furthermore, the capture of endangered animals is prohibited by the Portaria $\mathrm{n}^{\circ} 118 \mathrm{-N}$ (art. $11^{\circ}$ ), which prevents the capture of swarms by trap nests, since they are nonspecific, one cannot control which species will be captured. These two articles show that the legislation interprets stingless bees as wild animals, and categorizes their keeping as wild animal captivity.

Still in this law, the art. $20^{\circ}$ prohibits the sale of breeding stock and for the formation of new herds and to serve as pets, contrary to the meliponiculture traditional habits and the current efforts to strengthen the activity. On the other hand, this legislation allows the IBAMA to use this resource for reintroduction programs or to implement breeding sites with a social, community, or demonstrative character (art. $12^{\circ}$ ), an excellent potential for stingless beekeepers, especially for endangered species. 
Later, in 1998, the Law N. 9,605 of Environmental Crimes was published (BRASIL, 1998), the highest instance that deals with the keeping of native species, which "Dispose about criminal and administrative sanctions derived from conducts and activities harmful to the environment, and other measures." According to art. $29^{\circ}$, "Specimens of wild fauna are all those belonging to native, migratory and any other species, aquatic or terrestrial, which have all or part of their life cycle occurring within the limits of the Brazilian territory, or Brazilian jurisdictional waters."

The same article determines that any interference or modification of a wild animal's nest, its keeping or commercialization of parts, eggs, nests, or derived products, is a crime when done without proper authorization. Thus, the Environmental Crimes Law creates the need for authorizations for both the keeping of stingless bees, framed in the definition of wild animals, and the commercialization of their products or nest parts.

In an attempt to make stingless beekeeping compatible for small producers, which were the majority of the public who raised stingless bees for domestic honey consumption, in 2004, the National Environment Council (Conama), in Resolução $N^{\circ} 346$ was the first to discipline the use of wild bees, regulate the implementation of meliponaries $\left(\right.$ art. $\left.1^{\circ}\right)$ and the capture of new colonies through trap nests (art. $3^{\circ}$ ) (BRASIL, 2004).

The resolution maintains the obligatoriness for authorization for the maintenance of stingless bees for herds with more than 50 colonies. It is also dedicated to the artisanal practice of meliponiculture of endemic species in the area where the meliponary is installed (art. $5^{\circ}$ ), reaffirmed by Normative Instruction $\mathrm{N}^{\circ} 169$ (BRASIL, 2008). However, in addition to the Ibama Federal Technical Register (instituted by Federal Law 6.938/1981), which is required of all breeders, there is no federal system for requesting authorization to handle stingless bees, automatically pushing any beekeeper with more than 50 colonies into the irregularity.

This rule makes it impossible for the sale of honey to be the primary income source of a family since each colony produces only approximately $4 \mathrm{~kg}$ of honey per year. The resolution still allows transportation between federative states, only for scientific purposes and only with authorization from IBAMA (art. $\left.6^{\circ}\right)$. This article considers the political divisions of the territory as predominant in the natural distribution of the species, without considering the different phytophysiognomies that the same state may present or else the continuity of the biomes between the political denominations.

The Resolution Conama $\mathrm{N}^{\circ} 346$ still regulates the trap nests and the requirement that colonies maintained and marketed come from artificial multiplication methods (art. $4^{\circ}$ ), preventing predatory extraction of colonies from live tree trunks (BRASIL, 2004). Although the Resolution does not allow the extraction of colonies from nature, it establishes that deforestation or enterprises facilitate the removal of swarms from their impact area (art. $7^{\circ}$ ). This Resolution takes a vital step considering initially that bees, as well as their breeding sites, are goods of common use for the people and also the importance of meliponiculture for the local economy and the sustainability of natural environments and agricultural systems. However, it emphasizes that bees are part of the native "wild fauna" since they live naturally outside captivity.

Like the Environmental Crimes Law of 2008 , art. $2^{\circ}$ of Instrução Normativa Ibama $N^{\circ} 7$ defines native wildlife as "every animal belonging to the native, migratory and any other non-exotic species, which has all or part of its life cycle occurring within the limits of Brazilian territory or Brazilian jurisdictional waters" (BRASIL, 2015).

The Normative Instruction $\mathrm{N}^{\circ} 7$ also categorizes establishments for the use and management of wild fauna in captivity (art. 3), which may be for conservation, research, or commercial purposes (BRASIL, 2015). Among the categories of commercial purposes, the one intended for commercialization is prohibited from reproducing individuals, a practice that is destined only 
for establishments defined as "commercial breeding sites". Once the reproduction process is a continuum in colonies of social insects, this regulation cannot be applied to this group.

In this case, the most appropriate definition of 'reproduction' would be that of artificial multiplication of rational colonies, and not of the individuals themselves, also not specified by Resolution 346 of Conama that deals with native bees (BRASIL, 2004). These establishments must have a Prior, an Installation, and a Use and Management Authorization if they maintain more than 50 colonies. Pre-existing breeding stock must be previously documented and authorized for capture, transport, or invoices issued by breeding or authorized traders. The use of trap nests is not regulated.

The aforementioned normative instruments did not mention any bee species. In 2014, the Portaria 444 of Conama (BRASIL, 2014) prohibited the capture, transport, storage, custody, handling, processing, and trade of species threatened with extinction, except for the sole purpose of research and conservation. The ordinance specifies bees in the thread of extinction in Brazil, namely: Melipona capixaba (uruçú-negra, urucu-capixaba); Melipona rufiventris (tujuba, uruçu-amarelado-cerrado); Melipona scutellaris (urucu-nordestina) and Partamona littoralis (boca-de-sapo-daparaíba), all with explored economic potential, widely cultivated by hobbyists and, especially in the case of Meliponas, with the historical socio-environmental role.

Although both laws interpret social bees under human care as "captive," they remain free and collaborate with ecosystem services. It leads many beekeepers to argue that stingless bees kept in meliponaries should be treated under the definition of "domestic fauna", described as:

a set of fauna species whose biological, behavioral and phenotypic characteristics were altered through traditional and systematic management and zootechnical improvement processes, making them strictly dependent on man, and may present a variable phenotype, but different from the wild species that originated them (BRASIL, 2018).

This view is based on publications of different species that deal with the relationship and traditional breeding with bees, and rationalization of cultivation boxes that allows species to be raised outside their natural habitat, disease management and feeding methods (AIDAR, 1996; AIDAR; CAMPOS, 1998; BRUENING, 2001; CONTRERA; MENEZES; VENTURIERI, 2011; KERR; CARVALHO-ZILSE; NASCIMENTO, 1996; NOGUEIRA-NETO et al., 1986; ROUBIK, 2018; VENTURIERI, 2008; VILLAS-BÔAS, 2012).

There is also evidence that the species Melipona quadrifasciata (mandaçaia), threatened with extinction, was, in fact, extinct in the state of Rio Grande do Sul and is being reintroduced by producers and hobbyists (DÍAZ et al., 2017; MARQUES et al., 2003; WITTER; BLOCHTEIN, 2009). Reintroduction is taking place in a disorderly manner and without due control over the genetic and ecological identity of the species, as it is not allowed, and for this reason, there are no parameters to be followed. However, it constitutes proof of the close dependence that this species has on man to re-establish itself in its once natural environment, and that these producers can become allies in the conservation of the species and the maintenance of the genetic variability and ecosystem services.

With the meliponiculture activity gaining recognition and considering the art. 80 from Complementary Law № 140 (BRASIL, 2011) that establishes as the responsibility of States the approval of the operation of wild fauna breeding sites, a lot of different state laws are being published. They have in common the fact that they are more aligned with the methods of capturing colonies by trap nest and the methods of multiplying the previously existing colonies. Some states have their legal instruments that regulate regional authorizations for breeding, and in some cases, without agreement with the Resolution Conama $N^{\circ} 346$, as shows the technical advice 00122/2018/CONJUR-MMA/CGU/AGU of the Legal Advice of the Union. 
For example, the Law 16.171 (SANTA CATARINA, 2013) and the Decree 178 (SANTA CATARINA, 2015) that regulates it, which stand out for liberating the handling of bees and their products, as well as the purchase of nests and brood combs, without the need to present proof of rural ownership, and, provided that the transport is done within the political limits of the state of Santa Catarina, by issuing an Animal Transit Guide (GTA). In the Rio Grande do Sul, there is the Law 14.763 (RIO GRANDE DO SUL, 2015) that regulates meliponiculture, and the Normative Instruction (IN) SEMA 3 (RIO GRANDE DO SUL, 2014) which is a list of the 24 species of native bees that are allowed to be kept in the state.

However, this list is widely criticized for excluding M. quadrifasciata, which is one of the most cultivated species, and some producers argue that it would be native. According to this IN, meliponaries with up to 100 colonies are exempt from obtaining the operating authorization (art. $7^{\circ}$ ), more permissive than the Portaria of Conama of 2004, that indicates 50 colonies. Besides, the transportation of colonies or part of them is permitted in the territory of Rio Grande do Sul, without authorization (art. $13^{\circ}$ ). Other states have initiatives, such as Law 13.905 in the state of Bahia (BAHIA, 2018), the Resolution CEMAAM 22 in Amazonas state (AMAZONAS, 2017), the Ad referendum Resolution 007 from Goiás (GOIÁS, 2017), Law 19.152 from Paraná (PARANÁ, 2017), and is pending the Project of Law 4.943 from Minas Gerais (MINAS GERAIS, 2014), each one with its peculiarities.

\section{STINGLESS PRODUCTS}

If the native bees breeding and commercialization presents obstacles, it is no different with their products. Stingless bee honey and propolis are subject to the rules of the Milk and Derivatives Division (DILEI), Ministry of Agriculture (MA) subordinate. The main guidelines are from Decree 9.013 (BRASIL, 2017), that dispose about the industrial and sanitary inspection of products of animal origin and present several advances about the previous Decree, 30.691 (BRASIL, 1952), that inserted bee products to the same regulations for butcher products, hunting, fishing, milk, and eggs.

They are also subject to the IBAMA Ordinance $N^{\circ} 117$ as they come from wild animals. However, this does not make any mention of bees or bee products. (BRASIL, 1997a).

Although native bees honey is found for sale in local stores, the marketing of stingless bee products is hampered by the lack of adequate specific quality parameters for honey and propolis, due to its exclusive and divergent characteristics of Apis sp. products. The Normative Instruction 11 (BRASIL, 2000) defines honey by its process of obtaining (2.2.2.), where it fits like the one obtained by "draining the uncapped combs without larvae"; "Pressing the combs without larvae"; "Centrifugation of uncapped combs without larvae," clearly ignoring the existence of bee species that do not form combs in their colonies, as is the case of all species of native bees.

This instruction also presents reference values for physical-chemical characteristics, designed to meet the demand for A. mellifera honey. However, several of these attributes are not achieved by the honey of stingless bees. Also, the large variability of characteristics that native bees exhibit, even though they are raised in the same place, is an indication that the legislation must establish parameters for each species (BILUCA et al., 2016; DUARTE et al., 2018).

As an example, honey from Melipona subntida (jandaíra), one of the most cultivated species in northeastern Brazil, does not meet the humidity and diastasis activity conformities (ALMEIDA-MURADIAN et al., 2013) and, in most studies, no native bee species meets the recommended maximum humidity values. M. quadrifasciata, grown throughout the Atlantic Forest, exhibits moisture values higher than twice the reference value (BILUCA et al., 2016 e refs.). In the case of Melipona mondury (urucu-amarela), only the activity of diastasis is within limits accepted by current legislation (ALVEZ et al., 2018). 
The "Selo Arte" was created with the Law N 13.680 (BRASIL, 2018) and brought advances to the marketing of stingless bee honey since artisanal products of animal origin, which underwent regional inspections (municipal or state) are now allowed to be commercialized throughout the national territory and must present, for this purpose, the Selo Arte and follow its rules of application on the packaging of handmade products. Like the MBEE company, which focuses on the dissemination of the use of products of native species in haute cuisine, which, from the Municipal Inspection Seal (SIM) of the municipality of Atibaia-SP, starts to market its products throughout the national territory. Another exceptional case is the PROJETO HEBORÁ, a collaborative network that trains peasant women for the meliponiculture and marketing of honey, which with "Selo Arte," finds the possibility of reaching a wider consumer audience and, consequently, supporting more families in vulnerable situations.

Thus, the "Selo Arte" regulation (Portaria CDA 01/2020) represents a reduction of stingless honey marketing bureaucracy, because it does not have inspection criteria at the federal level. Thus, in the states and municipalities where there are regulations for native bee honey, the products approved in the regional inspections and which fit as artisanal products are released from having the Federal Inspection Seal (SIF) to sell their products outside the municipality or state where they have undergone inspection process.

However, there is still a need to develop physical-chemical and sanitary criteria for the honey from stingless bees in several states. Another possibility is to update the criteria to fit the enormous diversity of species in different regions. For the elaboration of federal criteria, a considerable research effort would be necessary to define the differences in the physicochemical attributes of native honey, avoiding making the norm restrictive, to harm the commercialization of the products.

The diverse Brazilian biomes and the distinct biodiversity of each of them create geographical features, including the characterization of honey, which would be difficult to approach by federal laws, more general. There are state efforts to meet this demand. The pioneer was the state of Bahia, with the Portaria ADAB 207, which regulates the quality of honey for bees of the genus Melipona, and, if practical, could be extended to other genera by analogy as a method of integrating the standard (BAHIA, 2014).

In the state of São Paulo, there is the Technical Regulation on Identity and Standard of stingless honey, through Resolution SAA-52 (SÃO PAULO, 2017), based on the article by Camargo, Oliveira, and Berto (2017), covering 6 Genera of Meliponini. Such resolution needs revision and the inclusion of data of more bee species from different regions of the state of São Paulo. It would better contemplate the diversity of characteristics of their honey, which vary significantly, both according to the species and the region since the humidity, free acidity, $\mathrm{pH}$, and HMF index vary much more than what is predicted by the ordinance and still meet all the sanitary requirements necessary for consumption.

The state of São Paulo also has the State Plan for the Strengthening of the Beekeeping and Meliponiculture Production Chain (SÃO PAULO, 2018), which uses small administrative units to monitor activity. These units are used for other actions of an environmental nature and in need of pollination, such as forestry, production of avocado, cotton, and coffee, and became part of the survey of the number of colonies, bee pasture and honey production from the creation of this plan. With the infeasibility of knowing the entire population structure on a fine-scale of all bee species in the region, the adhesion of small units goes according to the recommendations for the conservation of wild and commercially exploited species (LINNELL, 2005).

\section{FINAL CONSIDERATIONS}

It is evident the concern and efforts that the federal and state spheres are investing in improving the practices of handling and processing the products of native bees, aiming to achieve the preservation objectives guaranteed by the constitution and also the guarantee of economic gains for the population. 
Empirical studies on specificities in genetic diversity, artificial nutrition, the spread of diseases and practices in obtaining by-products from stingless bees, for example, should be evaluated in the writing of standards that respect the biology of native social species so that they do not be an obstacle for the meliponiculture activity strengthening and the culture maintenance.

Currently, there are projects in process that will influence the future of the activity, the Project of Law $N^{\circ} 6560$ (BRASIL, 2019c), which institutes the National Policy to Encourage Honey Production and the Development of Quality Bee and Honey Products and Services, presents a series of potentially positive aspects for the beekeeping chains. However, it must be taken into consideration that the activity of meliponiculture is very different from the well-established apiculture.

The policy should encourage the development of techniques and technologies for meliponiculture, as well as prioritize meliponiculture over apiculture, considering that stingless bees are native to Brazil, unlike the widely cultivated $A$. mellifera. There is also a Project of Law that seeks to regulate the professions of Technologists in Apiculture and Meliponiculture and that of Specialist in Apiculture and Meliponiculture, which, if established, will boost the technologies of cultivation and exploration (BRASIL, 2019b).

The legislation must also incentive the keeping of Meliponini species in their areas of natural occurrence, including endangered species, to direct meliponiculture as an income-generating activity, to also become a conservation tool. Such policies may also include payment for environmental services for registered honey farmers who keep endangered species in their area of occurrence, dealt with in Project of Law $\mathrm{N}^{\circ} 5028$ (BRASIL, 2019a). Restrictions on the number of swarms of each species that can be maintained should be relaxed since the production of honey is small. The same applies to the restrictions that specify the species that can be attracted to trap nests since the beekeeper has no control over the attracted species.

There are groups of beekeepers that aim to make stingless bees domestic animals from the legal point of view, which would bring new problems for the conservation of bees at all levels, colonies, populations, and species, and would alter the interpretation of all the legislation mentioned in this brief history.

The possibility of transforming stingless bees into domestic animals from a legal point of view would damage their conservation. However, there is the possibility of treating meliponiculture without all the limitations of Resolution Conama $\mathrm{N}^{\circ}$ 346: determine basic rules for the activity, making income generation for the beekeepers compatible and the conservation of the Meliponines, changing the Environmental Crimes Law as an example of what happens with the fishing activity, and then, creating a National Policy of Meliponiculture, entirely based on technical-scientific aspects.

The Environmental Crimes Law treats fishing as an exception to Fauna, that is, as a fishing resource, except in cases of endangered species, governed by Law $\mathrm{N}^{\circ} 11,959$ (BRASIL, 2009). The need to review the Environmental Crimes Law is due to the hierarchy of federal laws over state ones, which would then take into account local specificities.

In addition to technical parameters on bee products that respect each species biology, these suggestions would be good alternatives to regulate meliponiculture as an activity that promotes sustainability. It meets the objectives established by the International Initiative for the Conservation and Sustainable Use of Pollinators (CONVENTION ON BIOLOGICAL DIVERSITY), maintaining, in addition to bee biodiversity, agricultural biodiversity and the conservation of pollination-dependent plants.

\section{NOTES}

1 | Interview given by the technician responsible for Eggs, Dairy and Honey of the Municipality of Santa Rosa de Lima, Luiz Miguel Rech, to Jaqueline Reginato Koser in 07/04/2020. 


\section{REFERENCES}

AIDAR, D. S. A Mandaçaia: biologia de abelhas, manejo e multiplicação artificial de colônias de Melipona quadrifasciata Lep. (Hymenoptera, Apidae, Meliponinae). Ribeirão Preto: Sociedade Brasileira de Genética, 1996.

AIDAR, D. S.; CAMPOS, L. A. O. Manejo e manipulação artificial de colônias de Melipona quadrifasciata Lep. (Apidae: Meliponinae). Anais da Sociedade Entomológica do Brasil, v. 27, n. 1, p. 157-159, 1998.

ALMEIDA-MURADIAN, L. B. et al. Comparative study of the physicochemical and palynological characteristics of honey from Melipona subnitida and Apis mellifera. International Journal of Food Science and Technology, v. 48, n. 8, p. 1698-1706, 2013

ALVES, A. S. Revisão dos estudos dos polinizadores do morangueiro no Brasil. Monografia de Agronomia. Universidade Federal da Fronteira Sul: Cerro Largo. 2019.

ALVEZ, R. M. O. et al. Physico-chemical parameters of honey from Melipona mondury Smith, 1863 (Hymenoptera: Apidae: Meliponini). Journal of Agricultural Science, v. 10, n. 7, p. 196-205, 2018.

AMAZONAS. Resolução Cemaam $n^{\circ}$ 22, de 2 de março de 2017. Estabelece normas para a criação, manejo, transporte e comercialização de abelhas sem ferrão (meliponídeos) e seus produtos e subprodutos no estado do Amazonas e dá outras providências. Diário Oficial do Estado. 2017. Online on: <https://www.legisweb.com.br/ legislacao/?id=342526>. Access: 20 jan. 2019.

AME Blumenau. Online on: <http://ameblumenau.org/>. Access: 07 apr. 2020.

ASSOCIAÇÃO PAPA-MEL DE APICULTORES DE ROLANTE. Projeto Manduri: sustentabilidade socioambiental e conservação da Mata Atlântica. Ficha Projeto $n^{\circ} 237$. Ministério do Meio Ambiente, 2006. Online on: <http:// www.mma.gov.br/informma/item/8106-rs-rolante>. Access: 22 jan. 2019.

ATHAYDE, S.; STEPP, J. R.; BALLESTER, W. C. Engaging indigenous and academic knowledge on bees in the Amazon: implications for environmental management and transdisciplinary research. Journal of Ethnobiology and Ethnomedicine, v. 12, n. 26, p. 1-19, 2016.

BAHIA. Portaria Adab No 207, de 21 de novembro de 2014. Aprova o Regulamento Técnico de Identidade e Qualidade do Mel de Abelha social sem ferrão, gênero Melipona, conforme anexo a esta Portaria, com aplicação em todos os estabelecimentos de produtos das abelhas e derivados registrados sob a égide do Serviço de Inspeção Estadual. Online on: <https://sogi8.sogi.com.br/Arquivo/Modulo113.MRID109/Registro24666/portaria\%20 adab\%20n\%C2\%BA\%20207,\%20de\%2021-11-2014.pdf>. Access: 22 jan. 2019.

BAHIA. Lei No. 13.905, de 29 de janeiro de 2018. Dispõe sobre a criação, o comércio, a conservação e o transporte de Abelhas Nativas sem Ferrão (meliponíneos), no estado da Bahia. Diário Oficial do Estado, Salvador, BA, 31 de janeiro de 2018. Online on: <http://egbanet.egba.ba.gov.br/portal/edicoes/download/3542>. Access: 20 dec. 2018.

BALLIVIÁN, J. P. Abelhas Nativas sem Ferrão. São Leopoldo: Oikos. 128 p. 2008.

BAPTISTA, P. et al. Metodologia para avaliar a adaptação de abelhas Meliponini (Hymenoptera: Apidae) às condições de cultivos protegidos. Embrapa Recursos Genéticos e Biotecnologia. In: CONGRESSO BRASILEIRO DE ENTOMOLOGIA, 27.; CONGRESSO LATINO-AMERICANO DE ENTOMOLOGIA, 10., Gramado. Saúde, ambiente e agricultura. Anais... Gramado: SEB, 2018.

BARBIÉRI, C. J. Caracterização da meliponicultura e do perfil do meliponicultor no estado de São Paulo: ameaças e estratégias de conservação de abelhas sem ferrão. [s.l.] Dissertação de Mestrado. Programa de Pós-Graduação em Sustentabilidade. Escola de Artes, Ciências e Humanidades. Universidade de São Paulo, 2018.

BARBOSA, D. B. et al. As abelhas e seu serviço ecossistêmico de polinização. Revista Eletrônica Científica da UERGS, v. 3, n. 4, p. 694-703, 2017.

BILUCA, F. C. et al. Physicochemical profiles, minerals and bioactive compounds of stingless bee honey (Meliponinae). Journal of Food Composition and Analysis, v. 50, p. 61-69, 2016. 
BONATTI, V. et al. Evidence of at least two evolutionary lineages in Melipona subnitida (Apidae, Meliponini) suggested by mtDNA variability and geometric morphometrics of forewings. Naturwissenschaften, v. 101, n. 1, p. 17-24, 2014.

BRASIL. Decreto da Presidência da República N³0.691, de 29 de março de 1952. Aprova o novo Regulamento da Inspeção Industrial e Sanitária de Produtos de Origem Animal. Diário Oficial da União, Rio de Janeiro, RJ, 29 de março de 1952. Online on: <http://www2.camara.leg.br/legin/fed/decret/1950-1959/decreto-30691-29-marco1952-339586-normaatualizada-pe.pdf>. Access: 2 dec. 2018.

BRASIL. Portaria Ibama N 117, de 15 de outubro de 1997a. Dispõe sobre a comercialização de animais vivos, abatidos, partes e produtos da fauna silvestre. Diário Oficial da União, Brasília, DF, Seção I, 16 de outubro 1997. p. 23.489/490. Online on: <http://www.ibama.gov.br/phocadownload/fauna/faunasilvestre/1997_ibama_ portaria_117-1997_comercio-de-fauna-silvestre-nativa.pdf>. Access: 18 dec. 2018.

BRASIL. Portaria do Ministério do Meio Ambiente Nº188-N, de 15 de outubro de 1997b. Portaria do Ministério do Meio Ambiente №188-N, de 15 de out. de 1997. O Presidente do Instituto Brasileiro do Meio Ambiente e dos Recursos Naturais Renováveis - Ibama, usando das atribuições que the são conferidas pela Lei no 7.735 , de 22 de fevereiro de 1989, tendo em vista o disposto no art. 6o, letra "b", da Lei № 5.197, de 03 de janeiro de 1967; Lei № 6.938/81 e o que consta no Processo Ibama № 02001.002877/96-94. Diário Oficial da União, Brasília, DF, 17 de novembro de 1997. Online on: <http://licenciamento.cetesb.sp.gov.br/legislacao/federal/portarias/1997_Port_ IBAMA_118.pdf>. Access: 19 dec. 2018.

BRASIL. Lei № 9.605, de 12 de fevereiro de 1998. Dispõe sobre as sanções penais e administrativas derivadas de condutas e atividades lesivas ao meio ambiente, e dá outras providências. Diário Oficial da União, Brasília, DF, 13 de fevereiro de 1998. Seção 1. Online on: <http://www.planalto.gov.br/ccivil_03/leis/I9605. htm>. Access: 17 dec. 2018.

BRASIL. Ministério da Agricultura e do Abastecimento. Instrução Normativa $N^{\circ}$ 11, de 20 de outubro de 2000. Regulamento Técnico de Identidade e Qualidade do Mel. Diário Oficial da União, Brasília, DF, 23 de outubro de 2000. Online on: <http://www.cidasc.sc.gov.br/inspecao/files/2012/08/IN-11-de-2000.pdf>. Access: 17 dec. 2018.

BRASIL. Resolução do Conselho Nacional de Meio Ambiente - Conama N 346, de 16 de agosto de 2004. Disciplina a utilização das abelhas silvestres nativas, bem como a implantação de meliponários. Diário Oficial da União, Brasília, DF, 17 de agosto de 2004. Seção 1. Online on: <http://www2.mma.gov.br/port/conama/legiabre. cfm?codlegi=448>. Access: 22 jan. 2019.

BRASIL. Instrução Normativa do Ministério do Meio Ambiente $N^{\circ} 169$, de 20 fevereiro de 2008. Aprova a Estrutura Regimental do Ibama. Diário Oficial da União, Brasília, DF, 21 de fevereiro de 2008. n. 35, Seção 1, p. 57. Online on: <http://www2.mma.gov.br/port/conama/legiabre.cfm?codlegi=585>. Access: 20 jan. 2019.

BRASIL. Lei № 11.959, de 29 de junho de 2009. Dispõe sobre a Política Nacional de Desenvolvimento Sustentável da Aquicultura e da Pesca, regula as atividades pesqueiras, revoga a Lei n. 7.679, de 23 de novembro de 1988, e dispositivos do Decreto-Lei n. 221, de 28 de fevereiro de 1967, e dá outras providências. Diário Oficial da União, Brasília, DF, 30 de junho de 2009. p. 1. Online on: <http://www.planalto.gov.br/ccivil_03/_Ato2007-2010/2009/ Lei/L11959.htm>. Acesso 22 jan. 2019.

BRASIL. Lei Complementar N. 140, de 8 de dezembro de 2011. Fixa normas, nos termos dos incisos III, VI e VII do caput e do parágrafo único do art. 23 da Constituição Federal, para a cooperação entre a União, os Estados, o Distrito Federal e os Municípios nas ações administrativas decorrentes do exercício da competência comum relativas à proteção das paisagens naturais notáveis, à proteção do meio ambiente, ao combate à poluição em qualquer de suas formas e à preservação das florestas, da fauna e da flora; e altera a Lei n. 6.938, de 31 de agosto de 1981. Diário Oficial da União, Brasília, DF, 9 de dezembro de 2011. Online on: <http://www.planalto.gov.br/ ccivil_03/LEIS/LCP/Lcp140.htm>. Access: 21 jan. 2019.

BRASIL. Lista Nacional Oficial de Espécies da Fauna Ameaçada de Extinção. Portaria no 444, de 17 de dezembro de 2014. Ministério do Meio Ambiente. Diário Oficial da União, Brasília, DF, 18 de dezembro de 2014, p. 121126. Online on: <http://www.icmbio.gov.br/portal/images/stories/docs-plano-de-acao/00-saiba-mais/04_-PORTARIA_MMA_N\%C2\%BA_444_DE_17_DE_DEZ_DE_2014.pdf>. Access: 22 jan. 2019. 
BRASIL. Instrução Normativa do Ibama $N^{\circ} 7$, de 30 de abril de 2015. Institui e normatiza as categorias de uso e manejo da fauna silvestre em cativeiro, e define, no âmbito do Ibama, os procedimentos autorizativos para as categorias estabelecidas. Diário Oficial da União, Brasília, DF, 06 de maio de 2015. Retificada em 11 de maio de 2015. Online on: <https://www.ibama.gov.br/phocadownload/fauna/faunasilvestre/2015_ibama_in_07_2015_ autorizacao_uso_fauna_empreendimentos.pdf>. Access: 13 jan. 2019

BRASIL. Decreto da Presidência da República No 9.013, de 29 de março de 2017. Regulamenta a Lei no 1.283, de 18 de dezembro de 1950, e a Lei no 7.889, de 23 de novembro de 1989, que dispõem sobre a inspeção industrial e sanitária de produtos de origem animal. Diário Oficial da União, Brasília, DF, 30 de março de 2017. Online on: <http://www.planalto.gov.br/ccivil_03/LEIS/L1283.htm>. Access: 13 jan. 2019.

BRASIL. Lei № 13.680, de 14 de junho de 2018. Altera a Lei № 1.283, de 18 de dezembro de 1950, para dispor sobre o processo de fiscalização de produtos alimentícios de origem animal produzidos de forma artesanal. Poder Executivo, Brasília, Distrito Federal,14 de junho de 2018. Online on: <http://www.planalto.gov.br/ccivil_03/_ ato2015-2018/2018/Lei/L13680.htm>. Access: 13 jan. 2019.

BRASIL. Câmara dos Deputados. Projeto de Lei $\mathbf{N}^{\circ} \mathbf{5 . 0 2 8}$, de 2019a. Institui a Política Nacional de Pagamento por Serviços Ambientais; altera as Leis n. 8.629, de 25 de fevereiro de 1993, e 8.212, de 24 de julho de 1991; e dá outras providências. Online on: <https://legis.senado.leg.br/sdleg-getter/ documento?dm=8006958\&ts=1585786741269\&disposition=inline>. Access: 07 apr. 2020.

BRASIL. Câmara dos Deputados. Projeto de Lei $N^{\circ}$ 6.492, de 2019b. Regulamenta as profissões de Tecnólogo em Apicultura e Meliponicultura e de Especialista em Apicultura e Meliponicultura. Online on: <https://www. camara.leg.br/proposicoesWeb/fichadetramitacao?idProposicao=2234516>. Access: 07 apr. 2020.

BRASIL. Senado Federal. Projeto de Lei $\mathbf{N}^{\circ}$ 6.560, de 2019c. Institui a Política Nacional de Incentivo à Produção Melífera e ao Desenvolvimento de Produtos e Serviços Apícolas e Meliponícolas de Qualidade. Online on: <https://legis.senado.leg.br/sdleg-getter/documento?dm=8058898\&ts=1583949682783\&disposition=inline >. Access: 07 apr. 2020.

BRUENING, H. Abelha Jandaíra. 2. ed. Mossoró: Fundação Guimarães Duque e Fundação Vingt-Un Rosado, 2001.

BUCHMANN, S. L. Buzz pollination of Cassia quiedondilla (Leguminosae) by bees of the genera Centris and Melipona. Bulletin of the Southern California Academy of Sciences, v. 73, n. 3, p. 171-173, 1974.

Buzz pollination in angiosperms. In: Handbook of Experimental Pollination Biology. [s.l: s.n.]. p. 73-113.

CAMARGO, J. M. F.; PEDRO, S. R. M. Catalogue of bees (Hymenoptera, Apoidea) in the Neotropical Region - online version. In: Meliponini Lepeletier, 1836. In MOURE, J. S.; URBAN, D.; MELO, G. A. R. (Org.). [s.I: s.n.].

CAMARGO, R. C. R.; OLIVEIRA, K. L.; BERTO, M. I. Stingless bee honey: technical regulation proposal. Brazilian Journal of Food Technology, v. 20, n. e2016157, p. 1-6, 2017.

CARVALHO, R. M. A. et al. Do emotions influence the motivations and preferences of keepers of stingless bees? Journal of Ethnobiology and Ethnomedicine, v. 14, n. 1, p. 1-11, 2018.

CHAM, K. O. et al. Pesticide exposure assessment paradigm for stingless bees. Environmental entomology, v. 48, n. 1, p. 36-48, 2019

CHANTHAYOD, S.; ZHANG, W.; CHEN, J. People's perceptions of the benefits of natural beekeeping and its positive outcomes for forest conservation: a case study in Northern Lao PDR. Tropical Conservation Science, v. 10, p. 1-11, 2017.

CONTRERA, F. A. L.; MENEZES, C.; VENTURIERI, G. C. New horizons on stingless beekeeping (Apidae, Meliponini). Revista Brasileira de Zootecnia, v. 40, p. 48-51, 2011.

CONVENTION ON BIOLOGICAL DIVERSITY. SBSTTA 7 Recommendation VII/7. Online on: <https://www.cbd.int/ recommendation/sbstta/?id=7047>. Access: 07 apr. 2020.

CORTOPASSI-LAURINO, M. et al. Global meliponiculture: challenges and opportunities. Apidologie, v. 37, n. 2, p. 275-292, 2006. 
DALMAGRO, A. Criadores de abelha sem ferrão querem que lei catarinense que regula o setor ganhe abrangência nacional. Online on: <https://www.amurel.org.br/noticias/index/ver/codMapaltem/44238/codNoticia/329166>. Access: 07 apr. 2020.

DE LA RÚA, P. et al. Conserving genetic diversity in the honeybee: comments on Harpur et al. (2012). Molecular Ecology, v. 22, n. 12, p. 3208-3210, 2013.

DÍAZ, S. et al. Report on the microbiota of Melipona quadrifasciata affected by a recurrent disease. Journal of Invertebrate Pathology, v. 143, n. 2017, p. 35-39, 2017.

DOS SANTOS, C. F.; OTESBELGUE, A.; BLOCHTEIN, B. The dilemma of agricultural pollination in Brazil: beekeeping growth and insecticide use. PLOS ONE, v. 13, n. 7, p. 1-13, 2018.

DUARTE, A. W. F. et al. Honey and bee pollen produced by Meliponini (Apidae) in Alagoas, Brazil: multivariate analysis of physicochemical and antioxidant profiles. Food Science and Technology, v. 2061, p. 1-11, 2018.

G1 BA. Criadores de abelhas sem ferrão fazem manifestação e reivindicam a regulamentação da atividade na BA. Online on: <https://g1.globo.com/ba/bahia/noticia/criadores-de-abelhas-sem-ferrao-fazem-manifestacaoe-reivindicam-a-regulamentacao-da-atividade-na-ba.ghtml>. Access: 07 apr. 2020.

GEHRK, R. Meliponicultura: o caso dos criadores de abelhas nativas sem ferrão no Vale do Rio Rolante (RS). Dissertação de Mestrado. Porto Alegre. Faculdade de Ciências Econômicas. Universidade Federal do Rio Grande do Sul, 2010.

GOIÁS. Resolução N007/2017 - Cesmarh de 05 de dezembro de 2017. Institui a normatização e cadastramento obrigatório para todos os criadores de abelhas silvestres nativas, no âmbito do estado de Goiás e define os procedimentos de uso e manejo, autorizações e demais providências que couber. Diário Oficial do Estado, Goiânia, GO, de 2 de janeiro de 2018. Online on: <http://www.secima.go.gov.br/images/imagens_migradas/ upload/arquivos/2018-03/resolucao-07-2017---abelhas-nativas.pdf>. Access: 19 jan. 2019.

GRUPO DE MELIPONICULTURA DO VALE DE SANTA CATARINA. Facebook: meliponicultoresdovale. Online on: <https://www.facebook.com/groups/meliponicultoresdovale/>. Access: 07 apr. 2020.

HARPUR, B. A. et al. Admixture increases diversity in managed honey bees: reply to De la Rúa et al. Molecular ecology, v. 22, n. 12, p. 3211-3215, 2013.

et al. Management increases genetic diversity of honey bees via admixture. Molecular Ecology, v. 21, n. 18, p. 4414-4421, 2012.

JAFFÉ, R. et al. Bees for development: Brazilian survey reveals how to optimize stingless beekeeping. PLOS ONE, v. 10, n. 3, p. 1-21, 2015.

KERR, W. E.; CARVALHO-ZILSE, G. A.; NASCIMENTO, V. A. Abelha Uruçu: biologia, manejo e conservação. Belo Horizonte: Acangaú. 143 p. 1996.

LAIKRE, L. Genetic diversity is overlooked in international conservation policy implementation. Conservation Genetics, v. 11, n. 2, p. 349-354, 2010.

LINNELL, J. D. C. Spatial aspects of managing natural resources and conserving biodiversity. Integrating the global and the local. [s.l.] Norsk institutt for naturforskning, 2005.

MADERSON, S.; WYNNE-JONES, S. Beekeepers' knowledges and participation in pollinator conservation policy. Journal of Rural Studies, v. 45, p. 88-98, 1 jun. 2016.

MARQUES, A. A. B. et al. Livro vermelho da fauna ameaçada de extinção no Rio Grande do Sul. Decreto $\mathrm{n}^{\circ}$ 41.672, de 11 de junho de 2002. Porto Alegre: FZB/MCT-PUCRS/Pangea. 52 p. 2003.

MBEE Mel de Terroir. Online on: <http://mbee.com.br/quem-somos.html>. Access: 07 apr. 2020.

MCGREGOR, S. E. Insect pollination of cultivated crop plants. Usda, p. 849, 1976. 
MELIPONICULTURA - ABELHAS BRASILEIRAS SEM FERRÃO. Facebook: apicultura.abelhassemferrao. Online on: <https://www.facebook.com/groups/apicultura.abelhassemferrao/>. Access: 07 apr. 2020.

MINAS GERAIS. Projeto de Lei de 28 de fevereiro de 2014. Dispõe sobre a criação, o comércio e o transporte de abelhas sem ferrão (meliponíneas) no estado de Minas Gerais. 2014. Online on: <https://www.jusbrasil.com.br/ diarios/67046067/al-mg-28-02-2014-pg-3>. Access: 15 jan. 2019.

MINISTÉRIO DO MEIO AMBIENTE. Princípio da precaução. Disponível em <https://www.mma.gov.br/clima/ protecao-da-camada-de-ozonio/item/7512>. Access: 20 apr. 20.

MUÑOZ, I. et al. Estimating introgression in Apis mellifera siciliana populations: are the conservation islands really effective? Insect Conservation and Diversity, v. 7, n. 6, p. 563-571, 2014.

NAZARENO, A. G.; DOS REIS, M. S. Where did they come from? Genetic diversity and forensic investigation of the threatened palm species Butia eriospatha. Conservation Genetics, v. 15, n. 2, p. 441-452, 2014.

NEGRÍN MUÑOZ, E. Mujeres mayas, abejas mayas. GeoGraphos. Revista Digital para Estudiantes de Geografía y Ciencias Sociales, v. 7, n. Especial IV Congreso PYDES, p. 1-12, 2016.

NOGUEIRA NETO, P. et al. Biologia e manejo das abelhas sem ferrão. São Paulo: Tecnapis. 54 p. 1986.

NSC TV. Associação de criadores de abelhas sem ferrão busca regularização da atividade. Online on: <https:// g1.globo.com/sc/santa-catarina/noticia/2019/08/22/associacao-de-criadores-de-abelhas-sem-ferrao-buscaregularizacao-da-atividade.ghtml>. Access: 07 apr. 2020.

NUNES SILVA, N.; HRNCIR, M.; IMPERATRIZ-FONSECA, V. L. A polinização por vibração. Oecologia Australis, v. 14, n. 1, p. 140-151, 2010.

PARANÁ. Lei N 19.152 de 02 de outubro de 2017. Dispõe sobre a criação, o manejo, o comércio e o transporte de abelhas sociais nativas (meliponíneos). Diário Oficial do Estado, Curitiba, PR, 02 de outubro de 2017. Online on: <http://extwprlegs1.fao.org/docs/pdf/bra175744.pdf>. Access: 15 jan. 2019.

PROJETO HEBORÁ. Produzido por asas e mãos femininas. Online on: <https://www.hebora.com.br/heborapg-83237>. Access: 07 apr. 2020.

RIO GRANDE DO SUL. Instrução Normativa Sema No 3, de outubro de 2014. Institui e normatiza a criação e conservação de meliponíneos nativos (abelhas sem ferrão), no estado do Rio Grande do Sul. Diário Oficial do Estado, Porto Alegre, RS, 01 de outubro de 2014. Online on: <https://www.agricultura.rs.gov.br/upload/ arquivos/201701/09152730-pnsap-2014-inst-normativa-institui-e-normatiza-a-criacao-e-conservacao-demeliponineos-nativos-no-rs-01-10.pdf>. Access: 22 jan. 2019.

RIO GRANDE DO SUL. Lei No 14.763, de 23 de novembro de 2015. Dispõe sobre a criação, o comércio e o transporte de abelhas sem ferrão - meliponíneas - no estado do Rio Grande do Sul. Diário Oficial do Estado, Porto Alegre, RS, 24 de novembro de 2015. Online on: <https://www.legisweb.com.br/legislacao/?id=310382>. Access: 15 jan. 2019.

ROUBIK, D. W. The pollination of cultivated plants: a compendium for practitioners. Balboa: Food And Agriculture Organization of the United Nations (FAO), 2018.

SANTA CATARINA. Lei $N^{\circ} 16.171$, de 14 de novembro de 2013. Dispõe sobre a criação, o comércio e o transporte de abelhas sem ferrão (meliponíneas) no estado de Santa Catarina. Diário Oficial do Estado, Florianópolis, SC, 18 de novembro de 2013. Online on: <http://leisestaduais.com.br/sc/lei-ordinaria-n-16171-2013-santa-catarinadispoe-sobre-a-criacao-o-comercio-e-o-transporte-de-abelhas-sem-ferrao-meliponineas-no-estado-de-santacatarina-2017-01-17-versao-compilada>. Access: 22 jan. 2019.

SANTA CATARINA. Decreto No 178, de 22 de maio de 2015. Regulamenta a Lei no 16.171, de 2013, que dispõe sobre a criação, o comércio e o transporte de abelhas sem ferrão (meliponíneas) no estado de Santa Catarina. Diário Oficial do Estado, Florianópolis, SC, 25 de maio de 2015. Online on: <https://www.legisweb.com.br/ legislacao/?id=285074>. Access: 22 jan. 2019. 
SANTIAGO, L. R. et al. Genetic variability in captive populations of the stingless bee Tetragonisca angustula. Genetica, v. 144, n. 4, p. 397-405, 2016.

SÃO PAULO. Resolução SAA-52, de 03 de outubro de 2017. Aprova o Regulamento Técnico de Identidade e Padrão do mel elaborado pelas abelhas da subfamília Meliponinae (Hymenoptera, Apidae), conhecidas por Abelhas sem Ferrão - ASF e os requisitos de processamento e segurança. Diário Oficial do Estado, São Paulo, SP, 17 de outubro de 2017. Online on: <http://www.imprensaoficial.com.br/DO/GatewayPDF.aspx?link=/2017/executivo\%20 secao\%20i/outubro/17/pag_0019_4CKAR84VP666UeBC66S9CLA4DSP.pdf>. Access: 22 jan. 2019.

SÃO PAULO. Plano de Fortalecimento da Cadeia Produtiva da Apicultura e da Meliponicultura do Estado. Secretaria de Agricultura e Abastecimento, 2018. Online on: <https://www.agricultura.sp.gov.br/media/13377plano-de-fortalecimento-da-cadeia-da-apicultura-e-meliponicultura-10-dez-2018.pdf>. Access: 22 jan. 2019.

SÃO PAULO. Portaria CDA 01, de 17 de janeiro de 2020. Estabelece normas e procedimentos para a obtenção do selo ARTE em produtos de estabelecimentos registrados no Centro de Inspeção de Produtos de Origem Animal na forma artesanal. Coordenadoria de Defesa Agropecuária do Estado de São Paulo.

SCHENEKAR, T.; LERCETEAU-KHLER, E.; WEISS, S. Fine-scale phylogeographic contact zone in Austrian brown trout Salmo trutta reveals multiple waves of post-glacial colonization and a pre-dominance of natural versus anthropogenic admixture. Conservation Genetics, v. 15, n. 3, p. 561-572, 2014.

SILVA, G. R. et al. Aspectos bioecológicos e genético-comportamentais envolvidos na conservação da abelha Jandaíra, Melipona subnitida Ducke (Apidae, Meliponini), e o uso de ferramentas moleculares nos estudos de diversidade. Arquivos do Instituto Biológico, v. 81, n. 3, p. 299-308, 2014.

VELTHUIS, H. H. W.; KOEDAM, D.; IMPERATRIZ-FONSECA, V. L. The males of Melipona and other stingless bees, and their mothers. Apidologie, v. 36, n. 2, p. 169-185, 2005.

VENTURIERI, G. C. Criação de Abelhas Indígenas sem Ferrão. Belém: Embrapa Amazônia Oriental, 2008.

VILLAS-BÔAS, J. Manual Tecnológico: mel de abelhas sem ferrão. Brasília: ISPN, 2012.

VINÍCIUS SILVA, R. et al. Importance of bees in pollination of Solanum lycopersicum L.(Solanaceae) in open-field of the Southeast of Minas Gerais State, Brazil. Hoehnea, v. 44, n. 3, p. 349-360, 2017.

WITTER, S.; BLOCHTEIN, B. Espécies de abelhas sem ferrão de ocorrência no Rio Grande do Sul. Porto Alegre: Versátil Artes Gráficas, 2009. 